\title{
UN AVANCE HACIA LA MUERTE DIGNA: EL CASO DE LA COMUNITAT VALENCIANA
}

\section{Fabiola M Meco Tébar}

Diputada Corts Valencianes

https://doi.org/10.33676/EMUI_nomads.55.18

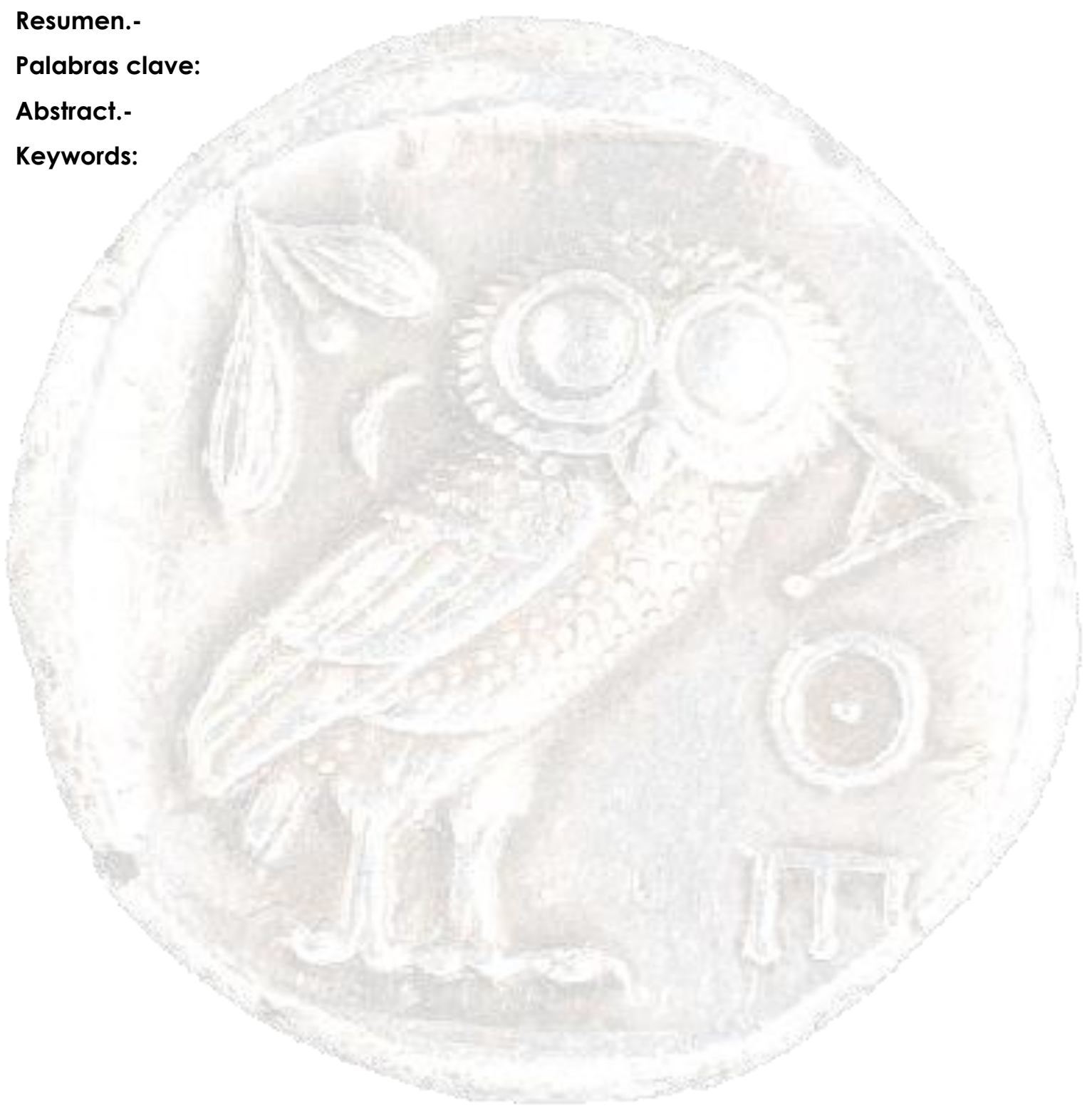

